\title{
PERAN SIRKULAR SAMPAH PRODUK UNTUK MENINGKATKAN PRODUKTIVITAS USAHA MASYARAKAT DESA BAGOREJO
}

\author{
Galih Candra Firmansyah $^{1 *}$, Ardhi Satrio Herlambang ${ }^{2}$, Wiwik Sumarmi ${ }^{1}$ \\ ${ }^{1}$ Universitas Muhammadiyah Sidoarjo, ${ }^{2}$ Universitas Wijaya Putra \\ *galihcandra.f@gmail.com
}

\begin{abstract}
The application of the waste bank is essentially a social engineering that encourages people to sort their waste. This study aims to analyze the management of the Waste Bank in Ampeldento Hamlet, Bagorejo Village, Gumukmas District, Jember Regency. In addition, this research will be implemented to analyze the social, economic and environmental impacts of waste banks in Ampeldento Hamlet, Bagorejo Village, Gumukmas District. The method using quantitative and qualitative. The implementation of data search activities was carried out by field observations and extensive interviews with informants. The analysis was carried out in a quantitative descriptive form in the form of tables and narrative views. The results of this study benefit from the management of community waste banks. The benefits of direct social impact are the Ampeldento Hamlet Garbage Bank urging residents to dispose of waste on their behalf, recommendations for disposing of waste in its place, and increasing waste bank customers, in addition to the impact on the environment, namely reducing waste generation in Ampeldento Hamlet. This creates a clean and this healthy environment and beneficial to the economy, namely where people have waste savings in the form of income that can be used to pay taxes, electricity, or buy groceries.
\end{abstract}

Keywords: Waste, Waste Management, Waste Bank

Abstrak

Penerapan bank sampah pada hakekatnya adalah rekayasa sosial yang mendorong masyarakat untuk memilah sampah. Penelitian ini bertujuan untuk menganalisis pengelolaan Bank Sampah di Dusun Ampeldento, Desa Bagorejo, Kecamatan Gumukmas, Kabupaten Jember. Selain itu research ini akan diimplementasikan guna mengalisis dampak sosial, ekonomi dan lingkungan bank sampah di Dusun Ampeldento Desa Bagorejo Kecamatan Gumukmas. Metode yang digunakan adalah kuantitatif serta kualitatif. Pelaksanaan kegiatan pencarian data dilaksanakan dengan observasi lapangan dan wawancara ekstensif dengan informan.Analisis dilakukan secara deskriptif kuantitatif yang berbentuk tabel dan narrative view. Hasil penelitian ini bermanfaat dari pengelolaan bank sampah masyarakat. Manfaat dampak sosial langsung yaitu Bank Sampah Dusun Ampeldento mengimbau warga untuk membuang sampah atas nama mereka, rekomendasi untuk membuang sampah pada tempatnya, dan bertambahnya nasabah bank sampah, selain itu pengaruh pada lingkungan yaitu berkurangnyatimbulan sampah di Dusun Ampeldento Ini menciptakan lingkungan yang bersih dan sehat serta menguntungkan perekonomian yaitu dimana masyarakat memiliki tabungan sampah berupa pendapatan yang dapat digunakan untuk membayar pajak, listrik, maupun membeli sembako.

Kata-kata kunci: Sampah, Pengelolaan sampah, Bank sampah 


\section{PENDAHULUAN}

Hidup bersih dalam lingkungan yang nyaman dan sehat adalah harapan semua masyarakat. Namun, hal ini lebih sulit dicapai karena kesadaran masyarakat yang berkurang. Saat ini, salah satu isu terkait kenyamanan lingkungan adalah sampah (Samudra \& Tembalang, 2019). Sampah adalah barang yang sudah tidak terpakai yang biasa dihasilkan oleh masyarakat. Secara umum dalam lingkup sosial seputar sirkular produk sampah ialah bahwa semua sampah tidak enak atau kotor dan harus dibakar atau dibuang dengan benar. Semua kegiatan penduduk akan menghasilkan sampah. Adalah tanggung jawab semua lingkup masyarakat yang ada untuk membuang sampah sesuai dengan tempat yang telah disediakan agar tidak berdampak buruk yang menyebabkan kerugian bagi masyarakat terutama dibidang lingkungan alam yang tercemar, tidak hanya pemerintah daerah setempat (Elamin et al., 2018).

Dengan bertambahnya jumlah sampah, maka perlu dikelola. Pengelolaan sampah yang non efektif dan efisien tanpa menggunakan metode dan teknologi pengelolaan sampah yang ramah lingkungan berdampak tidak baik bagi kesehatan manusia dan dapat mencemari lingkungan sekitar seperti hutan, sungai, rawa, pemukiman, maupun laut. Limbah jika tidak dibuang dengan benar dapat menimbulkan dampak negatif terhadap lingkungan, antara lain pencemaran, penyebab penyakit, penyumbatan saluran air dan banjir (Haryanti, \& Mahendra, 2020). Pengelolaan sampah di Indonesia merupakan masalah saat ini yang berdampak pada peningkatan timbulan sampah seiring dengan pertambahan jumlah penduduk. Analisis masalah pengelolaan sampah Indonesia, diantaranya kurangnya Pengelolaan sampah di Indonesia merupakan masalah saat ini yang berdampak pada peningkatan timbulan sampah seiring dengan pertambahan jumlah penduduk. Analisis masalah pengelolaan sampah Indonesia (Mahyudin, 2017)

Dengan ditetapkannya Peraturan dalam Kementrian LHK No. 32 Tahun 2009 mengenai keamanan dan kelestarian lingkungan, perlunya kesadaran oleh masayarakat sebagai warga negara yang baik agar selalu menjaga lingkungan supaya tetap asri. (Aryanti, 2016). Pendidikan publik tentang masalah lingkungan yang kompleks terkait dengan timbulan sampah diperlukan untuk meningkatkan kesadaran masyarakat. Faktor penyebab masalah lingkungan didasarkan pada pemikiran dan perilaku manusia. Partisipasi aktif warga menjadi faktor penting dalam upaya pengelolaan sampah.

Partisipasi akan kepedulian lingkungan dimulai dari hal-hal kecil dan dimulai dari individu. Perubahan yang dilakukan dapat "diwariskan" oleh dari kebiasaan-kebiasaan yang 
telah dilakukan dilingkungan sekitarnya termasuk masyarakat dan berujung pada perubahan besar (Asteria \& Heruman, 2016). Untuk itu, masyarakat perlu dilibatkan dalam tindakan untuk melindungi lingkungan dan mengambil jalan yang positif dan bermanfaat. Masyarakat harus selalu sadar akan peran strategisnya. Seperti disebutkan sebelumnya, salah satu peran strategis yang mungkin adalah berperan aktif dalam mitigasi pergantian iklim berbasis lingkungan (Alkhajar \& Luthfia, 2020). Terdapat beberapa klasifikasi limbah yang telah didsasarkan pada bentuknya, yaitu limbah yang sifatnya padat maupun limbah yang bersifat cair. Untuk itu, hal pertama yang harus dilakukan adalah mengidentifikasi berbagai jenis sampah di lingkungan, kemudian karena banyak sampah yang benar-benar digunakan, masih dapat digunakan, dan diolah mengklasifikasikan apa yang dapat didaur ulang. limbah.

Sampah bukanlah masalah jika ingin ditangani dengan serius, baik, benar dan bahkan profesional (Aminudin \& Nurwati, 2019). Sampah bahkan bisa menghasilkan apa yang bisa kita gunakan untuk menghasilkan pendapatan (alat tukar yaitu money). Dalam pengklasifikasiannya, sampah rumah tangga terbagi dalam tiga subkategori: baterai bekas, bola lampu bekas, dan limbah beracun seperti benda-benda yang berbahan kimia. Selanjutnya, sampah yang berbentuk padat yang sifatnya tidak dapat terurai dengan baik, seperti botol, kaleng, dan plastik PVC. Terakhir benda- benda yang dapat diurai oleh Bumi, seperti sisa-sisa sayuran dan hasil tanaman atau dedaunan, dimana Pengolahan sampah di TPS masih hanya berhenti pada pengolahan organic trash, sedangkan sampah anorganik belum diproses dengan optimal. Penggunaan sampah anorganik dalam produk yang dapat digunakan kembali diperlukan untuk membantu meminimalisisir tumpukan sampah di TPS dengan menampung sampah anorganik.

Proses pengumpulan sampah ataupun barang bekas yang sudah tidak terpakai dapat digunakan kembali berdasarkan bahan bekasnya tersebut kita dapat menganalisa dan mengelompokkan berdasarkan jenisnya sehingga dapat mengurangi jumlah barang bekas barang yang tidak digunakan masuk didalam TPS, serta dapat meminimalisir kerusakan lingkungan dari sampah yang menumpuk dan mengurangi total sampah yang masuk di TPS serta penghasilan yang didapatkan dari olah sampah dengan pemilaian sampah yang telah dihasilkan. (Diana \& Amalia, 2017). Dalam peraturan tentang optimalisasi sampah No. 18 ditahun 2008 dijelaskan bahwa penggolongan sampah menurut klasifikasinya dan sumber sampah berupa barang bekas yang sudah tak terpakai diatur sebagai berikut: 1. Limbah domestik, yaitu limbah padat dari sisa kegiatan rumah tangga, tidak termasuk pupuk kandang, serta limbah spesifik dan sifat lingkungan domestik. Limbah ini berasal dari rumah atau 
kompleks perumahan. 2. Limbah domestik bukan dari lingkup hasil rumah tangga, khususnya limbah domestik, tidak berasal dari rumah tangga dan lingkungan tempat tinggal tetapi dari sumber lain seperti rumah sakit, pusat perbelanjaan, instansi, sekolah, pasar traditional maupun modern, restoran, taman kota, pelabuhan, industri, hotel, dan tempat transaksi atau tempat ramai pengunjung lainnya. 3. Limbah tertentu, khususnya limbah domestik yang bersifat sejenis yang karena sifat konsentrasi maupun berdasarkan kuantitas memerlukan penanganan khusus, seperti bahan jadi dari limbah B3 seperti baterai bekas, tinta bekas dan lain sebagainya, limbah yang mengandung limbah B3 lainnya seperti limbah medis, limbah bencana, limbah pembongkaran, limbah yang tidak dapat didaur ulang yang dikelola dengan teknologi, limbah yang terjadi secara berkala (hasil gotong royong masyarakat)

Alur kegiatan dalam mengelola sampah yang termaktup dalam Undang-Undang olah sampah No. 18 pada tahun 2008 yang melaksanakan kegiatan kemanfaatan yang dilakukan dengan beberapa tahapan, pada tahap pertama yang perlu dilakukan ialah menimisasi sampah, khususnya kegiatan yang bertujuan untuk memulihkan timbulan sampah dari fasilitas produksi produksi sampah (rumah tangga, pasar dan lain-lain), pemanfaatan kembali sampah dari sumber latar tempat dalam olah sampah. Minimisasi sampah akan diatur dalam peraturan departemen tersendiri. Pada tahap selanjutnya pelaksanaan kegiatan pengolahan sampah, khususnya serangkaian kegiatan pengolahan sampah yang meliputi pemilahan (pengklasifikasian sampah menurut golongan dan tipe sifat nya), pengumpulan (proses awal pengumpulan sampah hasil dari masyarakat untuk diserahkan di TPS setempat atau tempat pembuangan sampah terpadu), serta kegiatan pemindahan sampah dari sumber ke sumber lain yang lebih efektif seperti dari TPS menuju di tempat lain yang telah dipersiapkan dalam pengelolaan sampahnya). Tahap terakhir ialah kegiatan pengolahan sampah secara terpadu, pengolahan hasil akhir (modifikasi jumlah sampah, posisi serta karakteristik dari produk sampah itu sendiri sehingga selanjutnya diolah, digunakan atau dikembalikan ke alam dan dibuang secara aktif) pengolahan sampah atau sisa dari penghasilan pemilaian sampah padea periode sebelumnya (Dobiki, 2018). Kegiatan yang sesuai dalam menggantikan pendekatan End of Chain yang selama ini ditempuh adalah menggunakan prinsip dari reuse, reduce, recycle, serta extend producer responsibility (EPR), pada penggunaan limbah untuk dimanfaatkan (waste use) dan final treatment. sampah di TPS dengan cara yang ramah lingkungan. Prinsip-prinsip ini berlaku di hulu ketika barang dan kemasan tidak terpakai dan menjadi limbah, hilir ketika barang dan kemasan mencapai akhir masa pakai dan menjadi limbah (Sekarningrum, 2017) 
Pada dasarnya, peraturan perundang-undangan terkait pemanfaatan sampah adalah mengatur cara pengelolaan sampah dengan konsep yang menghubungkan ekonomi sirkular pada kehidupan sehari-hari (circular product), yang merupakan cara pembuat produk (produsen) dalam menciptakan produk ataupun kemasan-kemasan yang lebih irit hingga lebih baik bagus secara kualitasnya dalam memproduksi hasil sampah tersebut, dan konsumen harus berkontribusi dalam kegiatan memilah produk untuk diproduksi kembali. terdapat ketentuan yang belum diatur dalam undang-undang, khususnya yang berkaitan dengan tugas produsen memberikan fasilitas untuk daur ulang produknya dan kewajiban produsen untuk memberikan sarana yang nyaman untuk memperbaiki barangnya (remanufaktur). Selain beberapa ketentuan yang telah ditetapkan, hal ini belum berfungsi sebagaimana mestinya karena peraturan untuk melaksanakan ketentuan tersebut belum dibuat oleh pemerintah (Qodriyatun et al., 2019). Proses pengimplementasian dalam prinsip ekonomi sirkular (round product), dimana nilai produk dan material dipertahankan dan digunakan selama mungkin, guna mengurangi kerugian sesedikit mungkin sehingga dapat meningkatkan produktivitas secara optimal bagi para pelaku kegiatan yang bersangkutan (Candra, 2021). Kesimpulan dari proses pengimplementasian ekonomi sirkular adalah untuk menyeimbangkan aspek lingkungan dan ekonomi, sehingga mereka dapat bekerja sama secara berkelanjutan (Kristina \& Larica, 2020).

Kegiatan optimalisasi sampah hadir sebagai bentuk upaya serta solusi terhadap masyarakat setempat dalam menyelesaikan permasalahan yang ada. Dalam sebuah komunitas Bank sampah semua orang yang berkontribusi dituntut untuk memiliki kekuatan untuk mengubah imajinasi kebanyakan orang tentang sampah yang tidak bernilai ekonomi. Tong sampah adalah wujud rekayasa sosial dalam hal pemberdayaan sebagai upaya untuk mengajarkan masyarakat cara memilah sampah dan mengedukasi warga setempat. Pembangunan serta proses pengembangan kegiatanbank sampah menjadi pendorong awal untuk mengajak masyarakat secara kolektif untuk mulai memberdayaan pemungutan sampah, serta memanfaatkan sampah, karena sampah dapat memiliki harga jika kita olah secara optimal, sehingga perlunya pengelolaan sampah ramah lingkungan menjadi budaya baru Indonesia.(Selomo \& Muammar, 2016). Kegiatan pengendalian sampah yang tidak terpakai dan dibiarkan begitu saja harus terus diimplementasikan dengan cara membuat bank pengumpulan sampah. Bank sampah merupakan suatu wadah yang memiliki tujuan visi dan misi dalam pengelolaan sampah rumah tangga. Adapun pengerjaannya dimulai dengan cara memilah sampah sesuai jenisnya terlebih dahulu kemudian menyimpannya di bank sampah 
yang dibuktikan dengan adanya buku tabungan sampah sebagai proses mengidentifikasi sampah beserta hasil yang didapatkan dalam proses pemilaian sampah yang akan diolah.

Dalam pengelolaan bank sampah yang berkelanjutan terdapat poin penting dalam upaya kegiatan Bank sampah agar dapat terealisasikan yaitu perlunya dilakukan perubahan paradigma dari pengumpulan dan pengolahan ke pengelolaan sampah dan pengelolaan berbasis pengurangan. Pengelolaan sampah dengan bank sampah secaramendasarmengubah perilaku pembuangansampah dalampemilahan dan penyimpanan sampah (Suwerda \& Kurniawan, 2019). Warga sekitar yang menabung dinamakan nasabah serti memiliki buku tabungan yang diberikan sebagai identitas transaksi, buku tabungan juga dapat digunakan untuk meminjam uang, yang akan dilunasi bersama dengan nominal uang yang diminta. Hal ini sangat membantu masyarakat mengingat dengan adanya pengelolaan bank sampah ini memiliki penghasilan baru serta mendorong kemandirian masyarakat untuk terus mengembangkan perekonomian secara nyata kedepannya.

Sampah/ barang bekas yang telah tersimpan selanjutnya akan memasuki tahap pembobotan berat sampah tersebut dan diberi imbalan dengan jumlah nominal uang tertentu, setelah itu akan dijual ke pabrik yang bekerja sama dengan bank sampah. Pendekatan yang relevan dengan konteks komunitas dan kebutuhan komunitas adalah kunci perubahan dalam meningkatkan perekonomian masyarakat (Takbiran, 2020). Selain itu dengan proses pengimplementasian bank sampah bagi masyarakat menjadikan masyarakat tahu akan keperdulian lingkungan yang ada. Kegiatan bank sampah ini tentunya sangat membantu masyrakat di Dusun Ampeldento, Desa Bagorejo terutama bagi kaum ibu-ibu yang mayoritas hanya sebagai ibu rumah tangga.

Data dari Dusun Ampeldento bulan Februari 2020, jumlah sampah di Dusun Ampeldento yaitu sebanyak $264 \mathrm{~kg} / \mathrm{bulan}$, timbulnn sampah juga terus bertambah, dengan total nasabah sebanyak 54 nasabah, rata-rata tiap nasabah menghasilkan 4,8 kg/bulan. Keberadaan bank sampah di perdesaan tidak lepas dari peran serta masyarakat dan pemerintah setempat. Terbentuknya perilaku pengelolaan sampah yang erkelanjutan di ank sampah masyarakat ke arah yang berkelanjutan dapat menjadi model perilaku masyarakat dalam pengelolaan sampah khususnya di pedesaan. Penelitian ini sejalan dengan penelitian sebelumnya oleh (Suwerda et al., 2019) bahwa pengelolaan sampah oleh bank sampah secara mendasar mengubah perilaku pembuangan dan pembakaran sampah di tempat pemilahan dan konservasi sampah sehingga sampah dapat disimpan, sebagaimana dibuktikan oleh kelompok 
pengelolaan sampah yang independen dari sistem perbankan. Sampah di wilayah Kabupaten Bantul pada tahun 2016 telah berkembang pesat menjadi 116 bank sampah, dimana 27 bank sampah yang beroperasi dan 82 bank sampah dalam tahap perencanaan pertumbuhan lanjutan dikembangkan untuk memberikan kemanfaatan bagi masyarakat di wilayah Bantul, Yogyakarta.

Bank sampah merupkan wujud investasi bagi nmasa depan selain sebagai upaya terhadap peningkatan masyarakat juga untuk menumbuhkan perekonomian, sisi lain yang dapat kita lihat termasuk kepedulian terhadap lingkungan (Suwerda et al., 2019). Partisipasi masyarakat merupkan salah satu faktor pentin g dalam pembangunan TPS. Adanya kegiatan gotong royong tentunya dapat meningkatkan masyarakat terhadap permasalahan-permasalan yang mungkin ada selama proses pelkasanaan Bank Sampah, alur partisipasi masyarakat mulai dari pelayanan nasabah, pengelolaan, klasifikasi dan penjualan sampah, hingga menabung dan mendapatkan penghasilan dari penjualan sampah tersebut. Penelitian ini bertujuan untuk menganalisis dampak dari pengelolaan bank sampah secara sosial, ekonomi, dan lingkungan di Dusun Ampeldento, Desa Bagorejo, Kecamatan Gumukmas.

\section{METODE PENELITIAN}

Pelaksanaan penelitian di Dusun Ampeldento, Desa Bagorejo, Kecamatan Gumukmas, Kabupaten Jember. Pemilihan lokasi di Desa Bagorejo karena merupakan tempat pengabdian kepada masyarakat dari program Kuliah Kerja Nyata. Penelitan ini dilakukan pada tanggal 21 Januari hingga 23 Februari 2020. Lingkup penelitian terbatas pada optimalisasi bank sampah di Ibu PKK Dusun Ampeldento, yang ditinjau dari segi pengelolaan bank sampah dan analisis dampak sosial, ekonomi dan lingkungan dari bank sampah klasifikasi sampah. disimpan di bank sampah. Pengambilan data dilaksanakan dengan tahapan observasi, kemudian tahapan dokumentasi dan wawancara langsung dengan pihak nasabah bank sampah, pengelola bank sampah, pengelola bank sampah, dan pemangku kepentingan. Pengukuran dilakukan berdasarkan jumlah sampah yang masuk ke bank sampah, serta jumlah sampah yang diklasifikasikan menurut komposisinya. Jumlah sampah dan komposisinya dinilai dari total sampah yang telah dikumpulkan oleh pelanggan di TPS.

Hasil data yang didapat kemudian dikelompokkan menjadi 2 kategori, yaitu data primer dan data sekunder. Data primer dilaksanakan dengan kegiatan wawancara serta observasi lapangan, sedangkan data sekunder dikumpulkan dengan mempelajari hasil dokumen maupun organisasi terkait dengan topik yang sedang diteliti. Untuk pengambilan 
data primer dalam pelaksanaan bank sampah dilakukan wawancara dengan 15 pengurus PKK yang mampu mendata sampah yang disetor warga, serta menyerahkan buku kepada warga. Hasil wawancara dan hasil observasi dokumen menunjukkan jumlah sampah yang ditimbun dari sampah domestik warga Dusun Ampeldento sudah menjadi pelanggan, dan warga Dusun Ampeldento sejumlah 5 pelanggan. Pengiriman dan pengumpulan sampah rumah tangga dimulai setiap hari rabu jam 10.00 WIB pagi hingga sore hari. Untuk kegiatan penimbangan bobot sampah dilakukan oleh kaum muda yang telah mengikuti mengikuti kelas sosial di masyarakat. Analisis data menggunakan pendekatan deskripsi kuantitatif yang disajikan dalam bentuk tampilan naratif dan tampilan tabel.

\section{HASIL DAN PEMBAHASAN}

Pengelolaan Bank sampah dimulai dengan mengedukasi warga dengan kegiatan pemilaian sampah, serta mengedukasi warga setempat tentang cara mengelola sampah yang benar untuk meminimalisir jumlah sampah yang terangkut ke tempat pengumpulan sampah akhir yaitu bank sampah. Selain itu, warga yang menyerahkan sampah akan mendapat tambahan pendapatan untuk kemandirian ekonomi warga, yang dapat digunakan untuk usaha simpan pinjam seperti koperasi, dengan bunga rendah sehingga sumber keuangan bank sampah dapat berputar dan berkembang, seperti serta tercapainya kesehatan lingkungan. Tujuan nyata pelaksanaan bank sampah adalah untuk meningkatkan ekonomi sehingga mengurangi tingkat pengangguran para ibu PKK yang mayoritas hanya sebagai ibu rumah tangga terbukti dengan dukungan ibu PKK yang telah menunjukkan ekstensinya sebagai kaum wanita untuk menggerakkan komunitasnya serta berperan aktif dalam mengelola sampah di lingkungannya serta melakukan kegiatan sosial dalam lingkungannya. Adapun tahapan tim pelaksana KKN dalam memberikan solusi pengelolaan bank sampah adalah sebagai berikut:

\section{Kegiatan Pemberdayaan Masyarakat}

Kegiatan community development yang berlangsung di ruang rapat di desa Ampeldento ini diawali dengan memerikan pengetahuan tentang proses pemilahan sampah. Antusiasme masyarakat dalam kegiatan ini sangat tinggi dimana partisipasi mencapai 100\% dari jumlah warga yang diundang. Kegiatan ini ertujuan untuk mensosialisasikan tentang pengelolaan sampah secara umum. Dokumen pertama yang disajikan berkaitan dengan arti klasifikasi yang sebenarnya (penggolongan jenis-jenis sampah). Selain itu peserta pelatihan dierikan 
materi tentang perbedaan sampah organik dan anorganik serta cara pengolahan masingmasing sampah tersebut sehingga dapat mengurangi ean di Tempat Pemuangan Akhir (TPS). Kegiatan ini tim lebih menekankan pada peran serta masyarakat dalam pengelolaan sampah dimana sampah harus dikelola dan diolah dari sumber sampah itu sendiri yang dalam hal ini adalah masyarakat (Diana et al., 2017). Selain literatur pengelolaan sampah secara umum kegiatan ini juga bertujuan untuk mengolah sampah anorganik khususnya plastik. Peserta pelatihan telah menyadari bahwa tidak seperti sampah organik yang mudah terdegradasi oleh mikroorganisme sampah anorganik memutuhkan waktu hingga 240 tahun untuk terurai secara alami sehingga daur ulang sampah anorganik sangat penting karena berguna dalam mengurangi volume sampah anorganik yang dikirim ke TPS.

\section{Proses Praktik Pemilaian Sampah Dilapangan}

Setelah sosialisasi tentang pengolahan bank sampah secara umum, kegiatan pelatihan ini dilanjutkan dengan praktik langsung. Kegiatan ini dimulai dengan pembelajaran warga setempat terhadap cara pemilaian sampah plastik anorganik dari TPS Desa Ampeldento. Tim KKN kami memberikan pemahaman kepada peserta yang hadir bahwasanya sampah yang berasal dari TPS merupakan sampah yang tidak higienis, sehingga dibutuhkan metode yang tepat dalam mengambil sampah di TPS yaitu dengan menggunakan masker dan sarung tangan. Sebelum sampah di kirim ke proses pengumpulan sampah diperlukan proses sterilisasi dengan cara mencuci sampah tersebut dengan sabun. Setelah proses sterilisasi dilaksnakan maka dapat dikirim ketempat pengumpulan sampah yaitu bank sampah.

Tabel 1. Jenis Sampah Non Organik yang di Setorkan di Bank Sampah Dusun Ampeldento yang telah dipilah sesuai dengan jenisnya.

\begin{tabular}{|c|l|c|c|}
\hline No. & \multicolumn{1}{|c|}{ Jenis Sampah } & \multicolumn{1}{|c|}{$\begin{array}{c}\text { Per } \\
\text { Minggu/Kg }\end{array}$} & $\begin{array}{c}\text { Per } \\
\text { Bulan/Kg }\end{array}$ \\
\hline 1. & $\begin{array}{l}\text { Kantong plastik belanjaan (hitam, putih, } \\
\text { pening, pembungkus mie, pembungkus minyak, pembungkus } \\
\text { kopi dan lain sebagainya) }\end{array}$ & $3 \mathrm{~kg}$ & $12 \mathrm{~kg}$ \\
\hline 2. & $\begin{array}{l}\text { lenis plastik ember (ember hitam, mainan } \\
\text { anak, gelas bening, paralon, botol bening, dan lain sebagainya) }\end{array}$ & $13 \mathrm{~kg}$ & $52 \mathrm{~kg}$ \\
\hline 3. & $\begin{array}{l}\text { Kertas (dus, kertas putih, buku, bungkus rokok, karton, kertas koran, } \\
\text { matte, } \\
\text { dan lain-lain) }\end{array}$ & $19 \mathrm{~kg}$ & $76 \mathrm{~kg}$ \\
\hline 4. & Logam (besi, aluminium, baja,katel, seng, & $18 \mathrm{~kg}$ & $72 \mathrm{~kg}$ \\
\hline
\end{tabular}




\begin{tabular}{|c|c|c|c|}
\hline 5. & Nilex (sepatu, selang dan lainnya) & $2 \mathrm{~kg}$ & $8 \mathrm{~kg}$ \\
\hline 6. & $\begin{array}{l}\text { Keamasan beling berkaca (botol fanta, minyak wangi, } \\
\text { pbat, dan lainnya) }\end{array}$ & $11 \mathrm{~kg}$ & $44 \mathrm{~kg}$ \\
\hline 7. & $\begin{array}{l}\text { Botol (botol bir, botol sirup, botol kecap, } \\
\text { botol marjan, botol saos, dan lainnya) }\end{array}$ & 12 biji & 48 biji \\
\hline
\end{tabular}

Sumber: data primer diolah 2020

Berdasarkan hasil data jenis sampah anorganik di TPS, komponen terpenting yang masuk ke TPS adalah jenis sampah kertas. Kertas bekas yang ada di bank bekas kemudian disortir berdasarkan jenis masing-masing kotak, kertas putih, buku, bungkus rokok, kardus, kertas koran, kertas buram dan lain-lain. Komponen tertinggi adalah kertas sobek, karena hampir semua rumah tangga memiliki kertas bekas yang sudah tidak terpakai lagi, antara lain buku pelajaran, koran, arsip, kertas HVS dan majalah. Sampah yang tertimbun seperti pada Tabel 1 berasal dari sampah domestik warga Dusun Ampeldento dengan jumlah pelanggan 5 orang. Masyarakat memilah sampah mereka sebelum mengirimnya ke pusat daur ulang. Pengetahuan masyarakat tentang jenis-jenis sampah dan cara pengelolaannya, khususnya sampah plastik,penting dalam mengembangkan bank sampah dan mengembangkan produksi produk daur ulang.

Pembangunan sirkulasi produk sampah terintegrasi dengan pembelajaran tmengenai prinsip 3R menjadi pengetahuan dasar bagi masyarakat untuk mengelola sampah pada sumbernya, yaitu sampah domestik. Dengan prinsip 3R, warga bisa memisahkan sampah organik dan non-organik. Manfaat dari kemampuan warga mengelola sampah dengan menerapkan prinsip 3R dan menabung di bank sampah telah menghasilkan manfaat langsung, tidak hanya dari segi ekonomi, tetapi juga dalam kesehatan, lingkungan, dengan kondisi masyarakat yang bersih, hijau, nyaman dan sehat. Lingkungan Dusun Ampeldento menjadi bersih dan lebih sehat dan nyaman karena masyarakat sudah mengimplementasikan program Bank sampah yang telah mereka pilah dari jenis organik dan anorganik. Berikut adalah perubahan kondisi sebelum dan sesuadah proses pengimplementasian bank sampah bagai ibu PKK di Dusun Ampeldento

\section{Tahap Evaluasi}

Kegiatan monitoring dan evaluasi dilakukan pada saat kegiatan pelatihan berlangsung untuk memastikan kecukupan proses dan keluaran sesuai dengan tujuan utama pelatihan, kegiatan 
ini atau tidak. Dari hasil monitoring dan evaluasi pada semua tahapan kegiatan diketahui tidak ada kendala yang berarti, sehingga peserta diklat sangat optimis kegiatan dapat berjalan dengan sendirinya tanpa dukungan tim pelaksana. Setelah dilakukan tahap monitoring dan evaluasi terhadap pengembangan Bank sampah didapatkan bahwa terdapat peningkatan yang baik terhadap masayarakat di Dusun Ampeldento seperti yang tertera ditabel sebagai berikut;

Tabel 2. Perubahan kondisi pengembangan bank sampah

\begin{tabular}{|c|l|l|l|}
\hline No & Sebelum & Kegiatan & Setelah dmplementasikan \\
\hline 1 & $\begin{array}{l}\text { Sosial, partisipasi } \\
\text { masyarakat rendah }\end{array}$ & $\begin{array}{l}\text { Pertemuan sosialisasi } \\
\text { kesadaran lingkungan } \\
\text { Lingkungan }\end{array}$ & $\begin{array}{l}\text { Masyarakat membuang sampah pada tempatnya dan } \\
\text { jumlah nasabah bank sampah yang melakukan } \\
\text { pemilahan sampah semakin bertambah mulai dari ibu- } \\
\text { ibu maupun para pemuda dan semuanya turut serta } \\
\text { dalam berkontribusi aktif penyetoran sampah }\end{array}$ \\
\hline 2 & $\begin{array}{l}\text { Secara ekonomi sampah } \\
\text { hanyalah barang yang } \\
\text { usang dan tidak memiliki } \\
\text { nilai jual. }\end{array}$ & $\begin{array}{l}\text { Melakukan kerjasama } \\
\text { enis sampah }\end{array}$ & $\begin{array}{l}\text { Masyarakat bisa menabung dan membayar pajak, } \\
\text { maupun membeli sembako }\end{array}$ \\
\hline 3 & $\begin{array}{l}\text { Lingkungan, mengalami } \\
\text { masalah banjir }\end{array}$ & $\begin{array}{l}\text { Mengajak warga gotong } \\
\text { royong membersihkan sampah } \\
\text { dan selokan serta proses } \\
\text { pemilaian sampah untuk } \\
\text { disetorkan ke bank sampah }\end{array}$ & $\begin{array}{l}\text { Penurunan jumlah sampah di lingkungan lebih bersih } \\
\text { dan sehat dibuang ke TPS, }\end{array}$ \\
& &
\end{tabular}

Sumber: Hasil Pengamatan Pengelolaan Bank Sampah

Munculnya bank sampah menjadi salah satu kegiatran yang efektif dalammengatasi permasalahan sampah di Dusun Ampeldento. Dampak sosial bank sampah di dusun Ampeldento mendorong warga untuk membuang sampah pada tempatnya, merekomendasikan pembuangan yang benar sebagai langkah awal dalam pengelolaan sampah selanjutnya, 3R harus diketahui (reduce, reuse, recycle). Adanya bank sampah mendorong warga untuk memilah sampahnya sebelum dibuang ke TPS, selain itu warga dapat memilah sampahnya. Kegagalan pengelolaan sampah akan meningkatkan risiko warga menghadapi berbagai penyakit yang meningkatkan biaya kesehatan dan sosial, selain itu sampah yang dibuang ke sungai dan selokan dapat menyebabkan banjir. Hasil penelitian ini sejalan dengan temuan peneliti sebelumnya (Elsaid \& Aghezzaf, 2015), yang menyatakan bahwa diperlukan upaya penyadaran masyarakat untuk pengelolaan sampah yang berkelanjutan di negara berkembang. Dalam penelitian sebelumnya (Arif \& Sutrisna, 2012) menunjukkan bahwa kesadaran pengelolaan sampah telah meningkat. Secara keseluruhan, model yang menggunakan kerangka teori perilaku terencana dapat menjelaskan intensi 
perilaku pengelolaan sampah berkelanjutan dengan pendekatan optimum. Adapun pendekatan yang mempengaruhi warga dalam berpartisipasi dalam kegiatan keberlanjutan pengelolaan sampah, yaitu upaya penerapan teknologi yang memudahkan warga setempat, langkah selanjutnya dilakukan upayapendekatan institusional dimana salah satu mitigasinya upaya pengelolaan sampah yang berkelanjutan adalah dengan mendorong partisipasi masyarakat dalam pengelolaan sampah.

Dampak ekonomi bank sampah di Dusun Ampeldento, Desa Bagorejo dengan adanya bank sampah memberikan manfaat ekonomi berupa pendapatan tambahan. Manfaat ekonomi bank sampah dimanfaatkan warga untuk membayar pajak perumahan dan kebutuhan seharihari. Sampah dapat memiliki nilai ekonomis jika dipilah dan hasilnya tidak lagi berupa sampah melainkan berupa barang-barang yang bernilai ekonomis. Dampak lingkungan dari bank sampah di dusun Ampeldento adalah mengurangi jumlah sampah yang dievakuasi ke TPS setelah dipilah, selain mengurangi jumlah sampah yang menumpuk di TPS dan lingkungan sekitar menjadi bersih. Dengan adanya bank sampah, keberadaan sampah menjadi lebih efektif dan efisien karena lebih terjaga kelestariannya daripada terbuang atau dibakar.

\section{KESIMPULAN}

Pengelolaan bank sampah di Dusun Ampeldento, Desa Bagorejo telah menunjukkan sejumlah hal positif dari segi teknis operasional. Oleh karena itu, kehadiran bank sampah telah membentuk kemandirian dan otonomi warga melalui pembentukan kesadaran, pengetahuan dan kapasitas untuk mendorong partisipasi dalam pengelolaan sampah serta di lingkungan masyarakat khususnya bagi masyarakat yaitu ibu-ibu PKK. Dengan demikian, sampah telah meningkatkan produktivitas usaha dan menjadi penyelamat ekonomi masyarakat pedesaan, khususnya di Dusun Ampeldento, Desa Bagorejo, Kecamatan Gumukmas, Kabupaten Jember.

\section{UCAPAN TERIMA KASIH}

Penulis mengucapkan terima kasih kepada masyarakat Dusun Ampeldento dan Pusat LPPM Universitas Muhammadiyah Sidoarjo yang telah menyelenggarakan kegiatan KKN pengabdian kepada masyarakat di Desa Bagorejo, Kecamatan Gumukmas, Kabupaten Jember yang menjadi artikel ilmiah dalam tulisan ini. 


\section{DAFTAR PUSTAKA}

Alkhajar, E. N. S., \& Luthfia, A. R. (2020). Daur Ulang Sampah Plastik Sebagai Mitigasi Perubahan Iklim. Jurnal Penamas Adi Buana, 4(1), 61-64. https://doi.org/10.36456/penamas.vol4.no1.a2524

Aminudin, \& Nurwati. (2019). Pemanfaatan Sampah Plastik Menjadi Kerajinan Tangan Guna Meningkatkan Kreatifitas Warga Sekitar Institut Teknologi dan Bisnis Ahmad Dahlan ( ITB-AD ) Jakarta. JURNAL ABDIMAS BSI Jurnal Pengabdian Kepada Masyarakat, 2(1), 66-79. Retrieved from https://ejournal.bsi.ac.id/ejurnal/index.php/abdimas/article/download/4515/2943

Arif, M., Bendi, D., Toma-Sabbagh, T., \& Sutrisna, M. (2012). Construction waste management in India: an exploratory study. Construction Innovation, 12(2), 133-155. https://doi.org/10.1108/14714171211215912

Aryanti, T. R. T. (2016). Implementasi Pengelolaan Bank Sampah (Studi Di Bank Sampah "Saling Asih" Desa Larangan Kecamatan Candi Kabupaten Sidoarjo). Dinamika Governance : Jurnal Ilmu Administrasi Negara, 6(2), 148-159.

Asteria, D., \& Heruman, H. (2016). Bank Sampah Sebagai Alternatif Strategi Pengelolaan Sampah Berbasis Masyarakat di Tasikmalaya. Jurnal Manusia Dan Lingkungan, 23(1), 136.

Bintarsih Sekarningrum, D. Y. dan S. S. (2017). Pengembangan Bank Sampah Pada Masyarakat Di Bantaran Sungai Cikapundung. Universitas Padjadjaran, 1(5), 292-298. Retrieved from http://jurnal.unpad.ac.id/pkm/article/download/16414/8010

Candra, G. C. F. (2021). Analisis Produktivitas Styrofoam Di Masa Pandemi Covid-19 Menggunakan Metode Cobb Douglas Di PT KCS. Industri Inovatif: Jurnal Teknik Industri, 11(2), 123-132. https://doi.org/10.36040/industri.v11i2.3694

Diana, S., Marlina, M., Amalia, Z., \& Amalia, A. (2017). Pemanfaatan Sampah Plastik Menjadi Produk Kerajinan Tangan Bernilai Ekonomis Bagi Remaja Putus Sekolah. Jurnal Vokasi - Politeknik Negeri Lhokseumawe, 1(1), 68-73. https://doi.org/10.30811/vokasi.v1i1.570

Dobiki, J. (2018). Analisis Ketersedian Prasarana Persampahan Di Pulau Kumo Dan Pulau Kakara Di Kabupaten Halmahera Utara. Spasial, 5(2), 220-228.

Elamin, M. Z., Ilmi, K. N., Tahrirah, T., Zarnuzi, Y. A., Suci, Y. C., Rahmawati, D. R., ... Nafisa, I. F. (2018). Analysis of Waste Management in The Village of Disanah, District of Sreseh Sampang, Madura. Jurnal Kesehatan Lingkungan, 10(4), 368. https://doi.org/10.20473/jkl.v10i4.2018.368-375

Elsaid, S., \& Aghezzaf, E. H. (2015). A framework for sustainable waste management: challenges and opportunities. Management Research Review, 38(10), 1086-1097. https://doi.org/10.1108/MRR-11-2014-0264

Haryanti, S., Evi, G., \& Mahendra, W. (2020). Pengelolaan Lingkungan Hidup di Kota Yogyakarta. Jurnal Bioeksperimen, 60-68. https://doi.org/10.23917/bioeksperimen.v5i1.2795

Kristina, H. J., Kosasih, W., \& Larica, L. (2020). Ergonomi Partisipasi dalam Mempromosikan Pengelolaan Sampah Mandiri dan Daur Ulang Kemasan Tetra Pak. Jurnal Madani: Ilmu Pengetahuan, Teknologi, Dan Humaniora, 3(1), 132-140. 
https://doi.org/10.33753/madani.v3i1.79

Mahyudin, R. P. (2017). Kajian Permasalahan Pengelolaan Sampah Dan Dampak. Teknik Lingkungan, 3, 3(1), 66-74.

Qodriyatun, S. N., Nurhayati, S., Yulia, Q., Elga, I., Anih, A., Suryani, S., \& Prasetyawan, T. (2019). Sampah Plastik Dan Implikasi Kebijakan Pembatasan Plastik Sekali Pakai Terhadap Industri Dan Masyarakat. Berkas.Dpr.Go.Id. Retrieved from http://intranspublishing.com

Samudro, G., Samadikun, B. P., Sholehah, F. D., \& Tembalang, K. (2019). Edukasi Bank Sampah Dalam Rangka Meningkatkan Kinerja Sistem Pengelolaan Persawahan Kawasan Perumahan Permata Tembalang Kelurahan Kramas Kota Semarang. Jurnal Pasopati, 1(18), 116-121.

Selomo, M., Birawida, A. B., Mallongi, A., \& Muammar. (2016). Bank Sampah Sebagai Salah Satu Solusi Penanganan Sampah Di Kota Makassar. Jurnal MKMI, 12(4), 232240.

Suwerda, B., Hardoyo, S. R., \& Kurniawan, A. (2019). Pengelolaan Bank Sampah Berkelanjutan Di Wilayah Perdesaan Kabupaten Bantul. Jurnal Sains \&Teknologi Lingkungan, 11(1), 74-86. https://doi.org/10.20885/jstl.vol11.iss1.art6

Takbiran, H. H. T. (2020). Bank Sampah Sebagai Alternatif Strategi Pengelolaan Sampah Menuju Sentul City Zero Emission Waste Kabupaten Bogor. IJEEM - Indonesian Journal of Environmental Education and Management, 5(2), 165-172. https://doi.org/10.21009/ijeem.052.05 